\title{
PENGARUH PENDIDIKAN MEDIA FLASHCARD TERHADAP PENGETAHUAN ANAK TENTANG PEDOMAN UMUM GIZI SEIMBANG DI SD MUHAMMADIYAH 21 BALUWARTI SURAKARTA
}

\author{
Nisaul Maslakah ${ }^{1}$, Zulia Setiyaningrum $^{2}$ \\ ${ }^{1,2}$ Program Studi Ilmu Gizi Fakultas Ilmu Kesehatan Universitas Muhammadiyah \\ Surakarta. Jl. A. Yani, Pabelan, Kartasura, Surakarta. \\ Email: ${ }^{1}$ nisaulmaslakah@gmail.com, ${ }^{2}$ zuliasetiyaningrum@ymail.com
}

\begin{abstract}
ABSTRAK
Berdasarkan hasil survei pendahuluan yang telah dilakukan di SD Muhammadiyah 21 Baluwarti Surakarta menunjukkan bahwa 70,1\% siswa memiliki pengetahuan gizi seimbang yang kurang. Penelitian ini bertujuan untuk mengetahui pengaruh pendidikan media flashcard terhadap pengetahuan anak tentang pedoman umum gizi seimbang di SD Muhammadiyah 21 Baluwarti Surakarta. Penelitian yang digunakan adalah quasi experiment design dengan rancangan Non Randomized Control Group Pretest-Posttest. Subjek penelitian masing-masing 31 siswa sebagai kelompok perlakuan dan kelompok kontrol. Instrumen yang digunakan yaitu kuesioner Pedoman Umum Gizi Seimbang dengan 25 item pertanyaan. Media yang digunakan adalah flashcard. Hasil penelitian menunjukan bahwa ada pengaruh sebelum dan sesudah diberikan pendidikan dengan media flashcard terhadap pengetahuan anak tentang pedoman umum gizi seimbang. Hasil uji perbedaan (uji Man Whitney $U$ ) menunjukan nilai $\mathrm{p}=0.000$ yang artinya ada perbedaan pengetahuan Pedoman Umum Gizi Seimbang pada kelompok perlakuan yang diberikan media flashcard dengan kelompok kontrol.
\end{abstract}

Kata kunci: Media flashcard, pedoman umum gizi seimbang, pengetahuan gizi.

\footnotetext{
ABSTRACT

Based on the preliminary survey that has been done in SD Muhammadiyah 21 Baluwarti Surakarta shows that $70.1 \%$ of students have a less balanced nutrition knowledge. The objective of the study was to determine the effect of flashcard media education on children's knowledge about the general guidelines for balanced nutrition at SD Muhammadiyah 21 Baluwarti Surakarta. The research used was quasi experiment design with Non-Pretest-Posttest Randomized Control Group design. The subjects were 31 students as the treatment group and the control group. The instrument used was questionnaires General Guidelines Balanced Nutrition with 25 items of questions. The media used was flashcard. The results showed that there was influence before and after being given education with flashcard media to the child's knowledge about the general guidance of balanced nutrition. The difference test (Man Whitney U test) showed p-value $=0.000$ which
} 
means there was the difference of knowledge of General Guidance of Balanced Nutrition in the treatment group given flashcard media with the control group.

Keywords: Flashcard media, general nutrition balance guidelines, nutritional knowledge.

\section{PENDAHULUAN}

Gizi dan kesehatan mempunyai peranan yang sangat besar dalam membentuk kualitas sumber daya manusia yang sehat, cerdas dan produktif, karena gizi adalah dasar pertumbuhan fisik dan perkembangan kecerdasan sehingga menjadi faktor kritis kualitas SDM di Indonesia (Depkes RI, 2005). Permasalahan gizi yang terjadi di Indonesia saat ini sangat kompleks dan dipengaruhi oleh beberapa faktor, salah satunya ialah pengetahuan gizi yang kurang. Pengetahuan gizi seseorang berpengaruh terhadap sikap dan perilaku dalam memilih makanan dan selanjutnya akan berpengaruh pada keadaan gizi individu bersangkutan (Maharibe, Khawangian dan Bolang, 2014). Kurangnya pengetahuan gizi dikalangan masyarakat akan membuat masalah yang sangat besar dan berdampak pada penurunan kualitas kesehatan (Phalevi, 2012). Beberapa masyarakat masih ada yang mengikuti panutan praktek pola makan yang salah yaitu "4 Sehat 5 Sempurna", slogan tersebut dianggap tidak lagi memenuhi prinsip pemenuhan asupan gizi yang baik, karena hanya menekankan pada keanekaragaman, dan tidak menonjolkan pada aspek proporsi serta kecukupan pada setiap makanan (Achadi dkk., 2010).

Penelitian yang dilakukan Achadi dkk. (2010) menjelaskan bahwa sebagian besar ibu dan anak menjawab Empat Sehat Lima Sempurna sama dengan Gizi Seimbang. Penyampaian pesan gizi seimbang yang kurang optimal akan memberikan pemahaman yang salah sehingga akan berdampak besar bagi kesehatan dan kualitas hidup selanjutnya (Kemenkes, 2014), hal tersebut harus segera ditindak lanjuti dengan peningkatan pengetahuan tentang gizi seimbang yang benar.

Anak sekolah dasar merupakan sasaran strategis dalam perbaikan gizi masyarakat (Choi dkk., 2008). Upaya mengoptimalkan penyampaian Pesan Gizi Seimbang kepada masyarakat, diperlukan sosialisasi yang lebih aplikatif ke berbagai elemen masyarakat (Kemenkes, 2014). Pendidikan kesehatan gizi sebagai suatu proses dimana proses tersebut mempunyai input dan output. Suatu proses pendidikan kesehatan gizi dipengaruhi oleh banyak faktor, salah satunya ialah alat-alat bantu/media yang digunakan dalam proses pendidikan (Notoatmodjo, 2011). Media sangat berperan penting dalam peningkatan pengetahuan gizi pada anak (Eliana dan Sholikah, 2012).

Penggunaan media Flashcard akan mempermudah proses penerimaan pengetahuan, karenamedia kartu bergambar ini secara langsung akan menampilkan gambar-gambar asli, praktis, menarik dan mudah diingat (Satriana, 2013) selain itu, Glovar dkk. (2010) menjelaskan bahwa media flashcard telah diusulkan sebagai cara mudah untuk mengajarkan siswa keterampilan khusus yang baru. Anggarawati, Kristiantari, dan Asri (2014) menyatakan bahwa model pembelajaran dengan bantuan media flashcard mempunyai pengaruh yang signifikan terhadap penerimaan pengetahuan, media flashcard ini juga 
dapat digunakan sebagai media permainan.

Berdasarkan hasil survei pendahuluan yang telah peneliti lakukan di SD Muhammadiyah 21 Baluwarti Surakarta menunjukkan bahwa $70,1 \%$ siswa memiliki pengetahuan gizi seimbang yang kurang dan semua siswa menjawab bahwa Pedoman Umum Gizi Seimbang saat ini adalah Empat Sehat Lima Sempurna. Hal itu menunjukan bahwa siswa disekolah tersebut belum mengenal tentang konsep gizi seimbang.

Berdasarkan pemaparan diatas penulis tertarik untuk meneliti tentang pengaruh pendidikan media flashcard terhadap pengetahuan anak tentang pedoman umum gizi seimbang di SD Muhammadiyah 21 Baluwarti Surakarta.

\section{METODE PENELITIAN}

Jenis metode penelitian yang digunakan adalah quasi experiment design (eksperimen semu) dengan rancangan Non Randomaized Control Group PretestPosttest. Pada rancangan diawali dengan pretest pada kedua kelompok kemudian diberikan perlakuan setelah itu dilakukan pengukuran kembali atau posttest pada kedua kelompok tersebut. Teknik pengambilan sampel dalam penelitian ini menggunakan clutser random sampling berdasarkan kelas yakni pengambilan sampel secara berkelompok, dengan jumlah sampel masing-masing 31 siswa sebagai kelompok perlakuan dan kelompok kontrol. Penelitian ini dilaksanakan pada bulan November 2016 di SD Muhammadiyah 21 Baluwarti Surakarta sebagai kelompok perlakuan dan SD Muhammadiyah 7 Surakarta sebagai kelompok kontrol. Data pengetahuan diperoleh dengan menggunakan kuesioner pengetahuan pedoman umum gizi seimbang. Media yang digunakan dalam penelitian yaitu flashcard. Analisis data mengunakan analisis uji Independent Sampel T test.

\section{HASIL DAN PEMBAHASAN}

\section{Gambaran Umum Sekolah}

Penelitian ini dilakukan di SD Muhammadiyah 21 Baluwarti dan SD Muhammadiyah 7 Joyosuran. Kedua sekolah merupakan Amal Usaha Muhammadiyah (AUM) dalam bidang pendidikan. SD Muhammadiyah 21 Baluwarti dan SD Muhammadiyah 7 Joyosuran sama-sama terletak di daerah pedesaan yang terletak pada 1 Kecamatan yaitu Pasar kliwon. Jarak antara kedua SD $\pm 2,5 \mathrm{~km}$.

SD Muhammadiyah 21 Baluwarti merupakan sekolah Terakreditasi C (Cukup). Jumlah siswa di SD Muhammadiyah 21 Baluwarti pada tahun ajaran 2016/2017 sebanyak 100 siswa, sedangkan di SD Muhammadiyah 7 Joyosuran saat ini Terakreditasi B (Baik). Jumlah siswa pada tahun 2016/2017 sebanyak 165 siswa.

\section{Karakteristik Responden}

Karakteristik dalam penelitian ini terdiri dari jenis kelamin, usia, dan status gizi Indeks Massa Tubuh berdasarkan Umur (IMT/U).

Tabel 1. Karakteristik Responden Berdasarkan Jenis Kelamin

\begin{tabular}{ccccc}
\hline \multirow{2}{*}{$\begin{array}{c}\text { Jenis } \\
\text { Kelamin }\end{array}$} & \multicolumn{2}{c}{ Perlakuan } & \multicolumn{2}{c}{ Kontrol } \\
\cline { 2 - 5 } & $\begin{array}{c}\text { Jumlah } \\
(\mathbf{n})\end{array}$ & $\begin{array}{c}\text { Persentase } \\
(\boldsymbol{\%})\end{array}$ & $\begin{array}{c}\text { Jumlah } \\
(\mathbf{n})\end{array}$ & $\begin{array}{c}\text { Persentase } \\
(\boldsymbol{\%})\end{array}$ \\
\hline Laki-laki & 16 & 51,6 & 12 & 38,7 \\
Perempuan & 15 & 48,4 & 19 & 61,3 \\
\hline Total & 31 & 100 & 31 & 100 \\
\hline
\end{tabular}

Dari Tabel 1 dapat diketahui bahwa pada kelompok perlakuan, responden lakilaki lebih banyak dari pada responden perempuan yaitu $51,6 \%$, sedangkan pada kelompok kontrol sebagian besar responden berjenis kelamin perempuan yaitu sebesar $61,3 \%$. 
Tabel 2. Karakteristik Responden Berdasarkan Usia

\begin{tabular}{ccccc}
\hline \multirow{2}{*}{ Usia } & \multicolumn{2}{c}{ Perlakuan } & \multicolumn{2}{c}{ Kontrol } \\
\cline { 2 - 5 } & $\begin{array}{c}\text { Jumlah } \\
(\mathbf{n})\end{array}$ & $\begin{array}{c}\text { Persentase } \\
(\boldsymbol{\%})\end{array}$ & $\begin{array}{c}\text { Jumlah } \\
(\mathbf{n})\end{array}$ & $\begin{array}{c}\text { Persentase } \\
(\boldsymbol{\%})\end{array}$ \\
\hline 8 & 5 & 16,1 & 0 & 0 \\
9 & 12 & 38,7 & 10 & 32,3 \\
10 & 7 & 22,6 & 19 & 61,3 \\
11 & 7 & 22,6 & 1 & 3,2 \\
12 & 0 & 0 & 1 & 3,2 \\
\hline Total & 31 & 100 & 31 & 100 \\
\hline
\end{tabular}

Berdasarkan Tabel 2 usia responden pada penelitian berada pada kisaran umur 8 sampai 12 tahun. Pada kelompok perlakuan sebagian besar sampel berusia 9 tahun yaitu 38,7\%, sedangkan pada kelompok kontrol sebagian besar sampel berusia 10 tahun yaitu $61,35 \%$. Pada usia 8-12 tahun daya ingat anak mencapai intensitas paling besar dan paling kuat (Sulastri, Purna, Suyasa, 2014). Menurut Wong (2008) daya pikir atau kekuatan mental anak yang berbeda usia akan berbeda pula secara kualitatif. Semakin cukup umur, maka tingkat kematangan dan kekuatan seseorang akan lebih matang dalam berpikir dan bekerja (Wawan A dan Dewi, 2010).

Tabel 3. Karakteristik Responden Berdasarkan Status Gizi (IMT/U)

\begin{tabular}{ccccc}
\hline \multirow{2}{*}{ IMT/U } & \multicolumn{2}{c}{ Perlakuan } & \multicolumn{2}{c}{ Kontrol } \\
\cline { 2 - 5 } & $\begin{array}{c}\text { Jumlah } \\
(\mathbf{n})\end{array}$ & $\begin{array}{c}\text { Persentase } \\
(\boldsymbol{\%})\end{array}$ & $\begin{array}{c}\text { Jumlah } \\
(\mathbf{n})\end{array}$ & $\begin{array}{c}\text { Persentase } \\
(\boldsymbol{\%})\end{array}$ \\
\hline Kurus & 2 & 6.5 & 9 & 29.0 \\
Normal & 29 & 93.5 & 21 & 67.7 \\
Gemuk & 0 & 0 & 1 & 3.2 \\
\hline Total & 31 & 100 & 31 & 100 \\
\hline
\end{tabular}

Data karakteristik responden berdasarkan Indeks Massa Tubuh menurut Umur (IMT/U) dapat dilihat bahwa sebagian besar pada kelompok perlakuan dan kontrol memiliki status gizi dengan kategori normal yaitu masing-masing sebesar $93,5 \%$ dan $67,7 \%$.

\section{Karakteristik Orangtua}

Karakteristik pada penelitian ini dapat dilihat dari tingkat pendidikan orangtua dan pekerjaan orangtua.

Tabel 4. Karakteristik Keluarga Berdasarkan Pendidikan

\begin{tabular}{ccccc}
\hline & \multicolumn{2}{c}{ Perlakuan } & \multicolumn{2}{c}{ Kontrol } \\
\cline { 2 - 5 } Variabel & $\begin{array}{c}\text { Jumlah } \\
(\mathbf{n})\end{array}$ & $\begin{array}{c}\text { Persentase } \\
(\%)\end{array}$ & $\begin{array}{c}\text { Jumlah } \\
(\mathbf{n})\end{array}$ & $\begin{array}{c}\text { Persentase } \\
(\%)\end{array}$ \\
\hline Pendidikan & & & & \\
Ayah & & & & \\
SD & 10 & 32,3 & 4 & 16,1 \\
SMP & 6 & 19,4 & 7 & 38,7 \\
SMA & 12 & 38,7 & 16 & 41,9 \\
PT & 3 & 9,7 & 4 & 3,2 \\
\hline Pendidikan & & & & \\
Ibu & & & & \\
SD & 11 & 35,5 & 5 & 16,1 \\
SMP & 8 & 25,8 & 12 & 38,7 \\
SMA & 10 & 32,3 & 13 & 41,9 \\
PT & 2 & 6,5 & 1 & 3,2 \\
\hline
\end{tabular}

Hasil pengumpulan data karakteristik pendidikan orangtua, dapat dilihat bahwa sebagian besar pendidikan terakhir ayah pada kelompok perlakuan maupun kontrol yaitu pada tingkat SMA, masing-masing sebesar 38,7\% dan 51,6\%. Pendidikan terakhir ibu pada kelompok perlakuan sebagian besar pada tingkat SD yaitu $32,3 \%$, sedangkan pada kelompok perlakuan sebagian besar pada tingkat SMA yaitu $41,9 \%$.

Tabel 5. Karakteristik Keluarga Berdasarkan Pekerjaan

\begin{tabular}{lcccc} 
& \multicolumn{2}{c}{ Perlakuan } & \multicolumn{2}{c}{ Kontrol } \\
\cline { 2 - 5 } Variabel & $\begin{array}{c}\text { Jumlah } \\
(\mathbf{n})\end{array}$ & $\begin{array}{c}\text { Persentase } \\
(\boldsymbol{\%})\end{array}$ & $\begin{array}{c}\text { Jumlah } \\
(\mathbf{n})\end{array}$ & $\begin{array}{c}\text { Persentase } \\
(\boldsymbol{\%})\end{array}$ \\
\hline Pekerjaan & & & & \\
Ayah & & & 0 & 0 \\
Pedagang & 1 & 3,2 & 17 & 54,8 \\
Buruh/Tani & 16 & 51,6 & 1 & 3,2 \\
PNS & 0 & 0 & 0 & 0 \\
TNI/POLRI & 0 & 0 & 2 & 6,5 \\
Pensiunan & 1 & 3,2 & 11 & 35,5 \\
Wiraswasta & 13 & 41,9 & 0 & 0 \\
IRT & 0 & 0 & & \\
Pekerjaan & & & 0 & 0 \\
Ibu & & & 11 & 35,5 \\
Pedagang & 3 & 9,7 & 0 & 0 \\
Buruh/Tani & 15 & 48,4 & 0 & 0 \\
PNS & 0 & 0 & 0 & 0 \\
TNI/POLRI & 0 & 0 & 13 & 41,9 \\
Pensiunan & 0 & 0 & 7 & 22,6 \\
Wiraswasta & 5 & 16,1 & & \\
IRT & 8 & 25,8 & & \\
\hline
\end{tabular}


Tabel 5 menunjukan bahwa pada kelompok perlakuan dan kontrol sebagian besar pekerjaan ayah sebagai buruh/tani, masing-masing sebesar 51,6\% dan 54,8\%. Sedangkan pekerjaan ibu sebagian besar pada kelompok perlakuan sebagai buruh/tani yaitu sebesar $48,4 \%$ dan pada kelompok kontrol sebagai wiraswasta yaitu sebesar $41,9 \%$.

\section{Pengetahuan Pedoman Umum Gizi Seimbang (PUGS)}

Pengetahuan Pedoman Umum Gizi Seimbang dalam penelitian ini dikelompokan menjadi 2 yaitu pre test dan post test. Hal tersebut bertujuan untuk mengetahui pengaruh pemberian pendidikan Pedoman Umum Gizi Seimbang. Tingkat pengetahuan responden diukur dengan menggunakan kuesioner pengetahuan Pedoman Umum Gizi Seimbang yang berjumlah 10 indikator yang mencakup 25 item pertanyaan.

Pendidikan Pedoman Umum Gizi Seimbang pada kelompok perlakuan diberikan dalam bentuk permainan dengan media flashcard yang berisi penjelasan tentang materi pedoman umum gizi seimbang. Permainan dilakukan secara berkelompok, setiap kelompok terdapat 5 responden dan 1 fasilitator.
Tabel 6. Distribusi Kategori Pengetahuan Pedoman Umum Gizi Seimbang pada Setiap Kelompok

\begin{tabular}{lcccc}
\hline \multirow{2}{*}{ Variabel } & \multicolumn{2}{c}{ Perlakuan } & \multicolumn{2}{c}{ Kontrol } \\
\cline { 2 - 5 } & $\begin{array}{c}\text { Jumlah } \\
(\mathbf{n})\end{array}$ & $\begin{array}{c}\text { Persentase } \\
(\boldsymbol{\%})\end{array}$ & $\begin{array}{c}\text { Jumlah } \\
(\mathbf{n})\end{array}$ & $\begin{array}{c}\text { Persentase } \\
(\boldsymbol{\%})\end{array}$ \\
\hline Pre test & & & & \\
Kurang & 9 & 29,0 & 3 & 9,7 \\
Cukup & 18 & 58,1 & 20 & 64,5 \\
Baik & 4 & 12,9 & 8 & 25,8 \\
Post test & & & & \\
Cukup & 3 & 9,7 & 13 & 25,8 \\
Baik & 28 & 90,3 & 18 & 74,2 \\
\hline
\end{tabular}

Pada Tabel 6 menunjukkan bahwa tingkat pengetahuan kelompok perlakuan maupun kontrol pada saat pre test sebagian besar pada kategori cukup yaitu masing-masing sebesar $58,1 \%$ dan $64,5 \%$. Pada kelompok perlakuan dan kelompok kontrol mengalami perubahan setelah diberikan post test. Pada kelompok perlakuan responden yang memiliki tingkat pengetahuan kategori baik persentasenya meningkat 7 kali lipat dari pada pre test yaitu dari $12,9 \%$ menjadi 90,3\%, sedangkan pada kelompok kontrol persentasenya hanya meningkat $2,8 \mathrm{kali}$ lipat dari pada pre test. Peningkatan pengetahuan pada kelompok perlakuan lebih tinggi dari pada kelompok kontrol. Hasil tersebut sejalan dengan penelitian Muzzaki (2012) yang menyatakan bahwa hasil belajar siswa MI Islamiyah Bandengan Jepara yang menggunakan bantuan media flashcard secara signifikan lebih tinggi dari pada kelompok kontrol.

Tabel 7. Deskripsi Nilai Pengetahuan Pedoman Umum Gizi Seimbang pada Setiap Kelompok

\begin{tabular}{ccccccc}
\hline \multirow{2}{*}{ Variabel } & \multicolumn{6}{c}{ Kelompok } \\
\cline { 2 - 7 } & \multicolumn{2}{c}{ Perlakuan } & \multicolumn{2}{c}{ Kontrol } & \multicolumn{2}{c}{$\Delta$ pengetahan } \\
\cline { 2 - 7 } & Pre test & Post test & Pre test & Post test & Perlakuan & Kontrol \\
\hline Rata-rata & 65,29 & 88,13 & 72,26 & 77.87 & 22,84 & 5,42 \\
SD & 11,142 & 10,249 & 7,861 & 7,210 & 11,830 & 4,21 \\
Minimal & 44 & 60 & 52 & 60 & 0 & 0 \\
Maximal & 88 & 100 & 80 & 88 & 52 & 16 \\
\hline Nilai $\mathrm{p}$ & \multicolumn{2}{c}{$0.000^{\mathrm{a}}$} & \multicolumn{2}{c}{$0.000^{\mathrm{a}}$} & \multicolumn{2}{c}{$0.000^{\mathrm{b}}$} \\
\hline
\end{tabular}

\begin{tabular}{ll}
\hline Keterangan: & a. Paired Sample T Test \\
& b. Man Whitney
\end{tabular}

Berdasarkan Tabel 7 menunjukkan media flashcard nilai rata-rata pada saat bahwa pada kelompok perlakuan dengan pre test dan post test mengalami 
peningkatan yang lebih signifikan dibandingkan dengan kelompok kontrol yaitu dari $65,29 \pm 11,142$ menjadi $88,13 \pm$ 10,249 , sedangkan pada kelompok kontrol yaitu $72,26 \pm 7,861$ menjadi 77,87 \pm 7,210 .

Hasil uji Paired Sample T Test pada kelompok perlakuan diperoleh nilai $\mathrm{p}=0.000$ yang berarti Ho ditolak, artinya ada perbedaan pengetahuan Pedoman Umum Gizi Seimbang antara pre test dan post test pada kelompok perlakuan yang diberi pendidikan dengan media flashcard. Hal tersebut didukung oleh penelitian Puspitasari YA, Triyono, Joharman (2013) yang menyatakan bahwa penggunaan media flashcard dapat meningkatkan hasil belajar pada anak SDN 2 Sempor Kebumen. Proses pendidikan gizi akan berjalan secara efektif dan efisien apabila didukung dengan media, salah satunya adalah media visual seperti Flashcard. Rangsangan visual yang diberikan kepada seseorang dapat meningkatkan daya serap materi sebesar 30\% dibandingkan dengan membaca teks yang hanya 10\% (Cotento, 2010). Azabdaftari (2012) berpendapat bahwa media flashcard sangat baik digunakan untuk anak-anak yang masih dalam tahap pertumbuhan dan flashcard dapat merubah suasana kelas menjadi menyenangkan. Dengan adanya media tersebutanak dapat belajar sambil bermain, sehingga minat anak untuk belajar akan lebih besar dan pembelajaran akan lebih menyenangkan (Maghfiroh, 2013).

Hasil uji Paired Sample T Test pada kelompok kontrol menunjukan ada perbedaan pengetahuan Pedoman Umum Gizi Seimbang pada kelompok kontrol yaitu $\mathrm{p}=0.000$. Peningkatan pengetahuan yang tidak signifikan pada kelompok kontrol disebabkan karena proses pendidikan pada kelompok tersebut hanya dengan metode ceramah tidak menggunakan bantuan media. Menurut
Supariasa, (2002) metode ceramah tanpa media memiliki kelemahan yaitu kurang menarik dan sulit dipakai pada sasaran anak-anak, metode ceramah dapat membatasi daya ingat karena ceramah pada umumnya memakai hanya satu indera, yaitu indera pendengaran dan kadang-kadang melibatkan indera penglihatan.

Hasil uji Man Whitney $U$ pada $\Delta$ pengetahuan gizi diperoleh nilai $\mathrm{p}=0.000$ yang berarti nilai $(\mathrm{p}<0.05)$ maka Ho di tolak, artinya ada perbedaan pengetahuan Pedoman Umum Gizi Seimbang pada kelompok perlakuan yang diberikan media flashcard dengan kelompok kontrol. Hal tersebut sejalan dengan penelitian yang dilakukan Muzzaki (2012) yang menyatakan bahwa terdapat perbedaan hasil belajar antara kelompok perlakuan (pendidikan yang mengunakan bantuan media flashcard) dengan kelompok kontrol, pada kelompok perlakuan ratarata hasil belajar mencapai 74,17 sedangkan pada kelompok kontrol sebesar 72,41 .

Rata-rata pertanyaan pada kuesioner yang sulit dijawab oleh responden adalah pertanyaan nomor 9, yaitu tentang makanan pokok dengan persentase yang menjawab salah sebesar 51,6\%. Pengetahuan merupakan salah satu faktor yang mempengaruhi tindakan seseorang, jika seseorang mempunyai pengetahuan gizi yang baik maka tindakan dan perilaku seseorang terhadap gizi juga akan baik (Notoatmdjo, 2011). Pengetahuan Pedoman Umum Gizi Seimbang sangat penting untuk dikenalkan sejak dini pada kalangan masyarakat. Peningkatan pengetahuan anak usia sekolah salah satunya dengan melalui pendidikan. Program pendidikan kesehatan dan gizi sebagai salah satu cara untuk menerapkan intervensi kesehatan global secara sederhana dan efektif untuk memperoleh pendidikan yang lebih luas (Jukes, Drake dan Bundy, 2008). 


\section{KESIMPULAN}

1. Ada pengaruh sebelum dan sesudah diberikan pendidikan dengan media flashcard terhadap pengetahuan anak tentang pedoman umum gizi seimbang yaitu pada kelompok perlakuan responden yang memiliki tingkat pengetahuan kategori baik persentasenya meningkat 7 kali lipat dari pada pre test, sedangkan pada kelompok kontrol persentasenya hanya meningkat 2,8 kali lipat dari pada pre test.

2. Ada perbedaan pengetahuan anak tentang pedoman umum gizi seimbang pada kelompok pendidikan dengan media flashcard dengan kelompok kontrol dengan nilai $\mathrm{p}=0.000$.

\section{DAFTAR PUSTAKA}

Achadi, E., Pujonarti SA., Sudiarti T., Rahmawati, Kusharisupeni, Mardatillah, Putra W.K., 2010, Sekolah Dasar Pintu Masuk Perbaikan Pengetahun, Sikap, dan Prilaku Gizi Seimbang Masyarakat, Jurnal kesehatan Masyarakat Nasional, $5(1): 42-48$.

Anggarawati, A., Kristiantari, R., Asri, AS., 2014,Pengaruh Make a match Berbantuan Media Kartu Gambar terhadap Hasil Belajar IPS SD, Jurnal Mimbar PGSD Universitas Pendidikan Ganesha Jurusan PGSD. 2(1) : 1-4.

Azabdaftri, B., Mohammad A.M., 2012, Comparing Vocabulary Learnig of EFL learners by using to different strategies: Mobile learning vs. Flashcard, The Eurocall. 2(2).

Choi, E.-S., Shin, N.-R., Jung, E.-I., Park, H.-R., Lee, H.-M., dan Song, K.-H., 2008, A study on nutrition knowledge and dietary behavior of elementary school children in Seoul. Nutrition Research and Practice,2(4), 308-316. http://doi.org/10.4162/nrp.2008.2.4.308

Contento I., 2010, Nutrition Education second edition, Jones and Bartelett Publisers, Sudbury United States.

Departemen Kesehatan RI., 2005, Pedoman Perbaikan Gizi Anak Sekolah Dasar, dan Madrasah Ibtidaiyah, Direktorat Gizi Masyarakat, Jakarta.

Eliana D. dan Sholikah., 2012, Pengaruh Buku Saku Gizi Terhadap Tingkat Pengetahuan Gizi Pada Anak Kelas 5 Muhammadiyah Dadapan Desa Wonokerto Kecamatan Turi Kabupaten Sleman Yogyakarta, Jurnal KESMAS $U A D, 6(2): 62-232$.

Glover P., Thomas M., Derby K.M., Gower J., 2010, Using a Direct Instruction Flashcard System with Two Students with Learning Disabilities, Electronic Journal of Research in Educational Psychology. 8(2) : 457-472.

Jukes M.C.H., Drake L.J., Bundy D.A.P., 2008, School Health, Nutrition and Education for All, CABI Publishing International, Oxsfordshire UK. 
Kementerian Kesehatan., 2014, Peraturan Menetri Kesehatan Tentang Pedoman Gizi Seimbang,1-96, Jakarta.

Maghfiroh, L., 2013, Penggunaan Media Flashcard untuk Meningkatkan Hasil Belajar IPS pada Pembelajaran Tematik di Sekolah Dasar, Jurnal PGSD UNESA. 1 (2) : 0-126.

Maharibe CC., Kawengian SE., Bolang AL., 2014, Hubungan Pengetahuan Gizi Seimbang dengan Praktik Gizi Seimbang Mahasiswa Program Studi Pendidikan Dokter Angkatan 2013 Fakultas Kedokteran Universitas Sam Ratulangi, Jurnal e-Biomedik. 2(1) : 1-9.

Muzzaki, M.S., Antonius, T.W., Raharjo, T.J., 2012, Keefektifan Pembelajaran Bahasa Inggris Berbantuan Flashcard untuk Meningkatkan Hasil Belajar Siswa, Inovative Journal of Curiculum and Educational Technology. 1 (2).

Notoatmodjo, S., 2011,Promosi kesehatan dan Ilmu perilaku.Rienka Cipta, Jakarta.

Phalevi, AS., 2012, Determinan Status Gizi pada Siswa Sekolah Dasar, Jurnal Kesehatan Masyarakat. 7(2) : 122-126.

Puspitasari YA, Triyono, Joharman., 2013, Upaya Pembelajaran Bahasa Inggris dengan Penggunaan Media Flashcard pada Siswa Kelas V SDN 2 Sempor Kebumen Tahun Pelajaran 2013/2014, Jurnal Kalam Cendekia PGSD Kebumen. 6 (5).

Satriana, A., 2013, Meningkatkan Kemampuan Mengenal Lambang Bilangan 1 sampai 5 Melalui Media Flashcard bagi Siswa Tunagrahita Sedang, Jurnal Ilmiah Pendidikan Khusus.1(2) : 13-26.

Sulastri, K., Purna, I.N., Suyasa., I.N., 2014, Hubungan Tingkat Pengetahuan dan Perilaku Anak Sekolah tentang Hidup Bersih dan Sehat di Sekolah Dasar Negeri Wilayah Puskesmas Selemadeg Timur II, Jurnal Kesehatan Lingkungan. 4(1) : 99-106.

Supariasa, I.D.N., 2002, Pendidikan dan Konsultasi Gizi, Penerbit Buku Kedokteran EGC, Jakarta.

Wawan, A., Dewi., 2010, Teori \& Pengukuran Pengetahuan, Sikap, dan Perilaku Manusia, Nuha Medika, Yogyakarta.

Wong, Donna L., 2008, Buku Ajar Keperawatan Pediatrik Edisi 6, EGC, Jakarta. 